\title{
Sequential Mixed Cultures: From Syngas to Malic Acid
}

\section{Florian Oswald ${ }^{* \dagger}$, Stefan Dörsam ${ }^{* \dagger}$, Nicolas Veith, Michaela Zwick, Anke Neumann, Katrin Ochsenreither and Christoph Syldatk}

Technical Biology, Institute of Process Engineering in Life Sciences, Karlsruhe Institute of Technology, Karlsruhe, Germany

Synthesis gas (syngas) fermentation using acetogenic bacteria is an approach for production of bulk chemicals like acetate, ethanol, butanol, or 2,3-butandiol avoiding the fuel vs. food debate by using carbon monoxide, carbon dioxide, and hydrogen from gasification of biomass or industrial waste gases. Suffering from energetic limitations, yields of $\mathrm{C}_{4}$-molecules produced by syngas fermentation are quite low compared with ABE fermentation using sugars as a substrate. On the other hand, fungal production of malic acid has high yields of product per gram metabolized substrate but is currently limited to sugar containing substrates. In this study, it was possible to show that Aspergilus oryzae is able to produce malic acid using acetate as sole carbon source which is a main product of acetogenic syngas fermentation. Bioreactor cultivations were conducted in $2.5 \mathrm{~L}$ stirred tank reactors. During the syngas fermentation part of the sequential mixed culture, Clostridium ljungdahlii was grown in modified Tanner medium and sparged with $20 \mathrm{~mL} / \mathrm{min}$ of artificial syngas mimicking a composition of clean syngas from entrained bed gasification of straw (32.5 vol-\% CO, 32.5 vol-\% $\mathrm{H}_{2}, 16$ vol- $\% \mathrm{CO}_{2}$, and 19 vol-\% $\mathrm{N}_{2}$ ) using a microsparger. Syngas consumption was monitored via automated gas chromatographic measurement of the off-gas. For the fungal fermentation part gas sparging was switched to $0.6 \mathrm{~L} / \mathrm{min}$ of air and a standard sparger. Ammonia content of medium for syngas fermentation was reduced to $0.33 \mathrm{~g} / \mathrm{L}$ $\mathrm{NH}_{4} \mathrm{Cl}$ to meet the requirements for fungal production of dicarboxylic acids. Malic acid production performance of $A$. oryzae in organic acid production medium and syngas medium with acetate as sole carbon source was verified and gave $Y_{P} / \mathrm{s}$ values of $0.28 \mathrm{~g} / \mathrm{g}$ and $0.37 \mathrm{~g} / \mathrm{g}$ respectively. Growth and acetate formation of $C$. ljungdahlii during syngas fermentation were not affected by the reduced ammonia content and $66 \%$ of the consumed syngas was converted to acetate. The overall conversion of $\mathrm{CO}$ and $\mathrm{H}_{2}$ into malic acid was calculated to be $3.5 \mathrm{~g}$ malic acid per mol of consumed syngas or $0.22 \mathrm{~g}$ malic acid per gram of syngas.

Keywords: syngas, fermentation, Clostridium ljungdahlii, Aspergillus oryzae, malic acid, acetate, process coupling

\section{INTRODUCTION}

Nowadays most bulk chemicals are still based on fossil fuels like crude oil and natural gas. It is consensus that, due to dwindling resources and climate change, it is necessary to develop sustainable methods for the production of industrially relevant chemicals. Suitable candidates for these demands are various dicarboxylic acids because of their suitability to be used for the synthesis 
of various polymers, as was summarized by Lee et al. (2011). In 2004, the US Department of Energy selected the $\mathrm{C}_{4}$ dicarboxylic acids malic acid, fumaric acid and succinic acid to be one of the 12 most important platform chemicals produced from biomass (Werpy and Petersen, 2004). However, malic acid is still mostly produced from petroleum (Lohbeck et al., 2000, Miltenberger, 2000). It can be used for the synthesis of polymers for the food and pharmaceutical industries (Werpy and Petersen, 2004), as well as for many other bulk and fine chemicals. Some fungi from the genus Aspergillus, like Aspergilus flavus or Aspergilus oryzae, produce, under certain stress conditions, sizeable amounts of malic acid which is secreted to the culture medium. The development and optimization of production processes for A. flavus in the last decades leads to possible malic acid yields of $0.94 \mathrm{~g} / \mathrm{g}$ using glucose as carbon source (Peleg et al., 1988, 1989; Battat et al., 1991). A major disadvantage of A. flavus is the production of aflatoxins which makes its usage in fields of medicine or food industry impossible. The close relative, but not aflatoxin producing $A$. oryzae has also been investigated for the production of malic acid (Knuf et al., 2013). A strain developed by metabolic engineering achieved concentrations of $154 \mathrm{~g} / \mathrm{L}$ from $160 \mathrm{~g} / \mathrm{L}$ glucose (Brown et al., 2013). It was also possible to establish processes for malic acid production with metabolically engineered model organisms like E. coli or S. cerevisiae based on glucose (Moon et al., 2008; Zelle et al., 2008; Zhang et al., 2011). It could be shown that $A$. oryzae is able to convert several alternative carbon sources to malic acid, like glycerol or pentose sugars (i.e., xylose), which are also part of lignocellulosic material (Ochsenreither et al., 2014). The "food or fuel" debate shows the importance of developing biotechnological malic acid production based on sustainable carbon sources which are not competing with food or feed production. Therefore, alternative carbon sources based on lignocellulose, such as hydrolysates from lignocellulose separation or pyrolysis oil from thermal treatment of lignocellulosic biomass as substrate for malate production by Aspergilli would be conceivable. Other attempts to produce $\mathrm{C}_{4}$ molecules from lignocellulosic substrates focus on the production of n-butanol or butyric acid using anaerobic bacteria (Zhang et al., 2009). The most popular process for butanol production from anaerobic microorganisms is ABE (Acetone, Butanol, Ethanol) fermentation, which uses solventogenic bacteria of the genus Clostridium. Using different lignocellulosic and hemicellulosic substrates, final butanol concentrations of up to $18 \mathrm{~g} / \mathrm{L}$ are reported (Schiel-Bengelsdorf et al., 2013). As for other biotechnological processes, $\mathrm{ABE}$ fermentation is limited to sugar containing substrates. In recent years industrial exhaust gases like steel mill off-gas (Köpke et al., 2011) and syngas, a mixture of $\mathrm{H}_{2}$, $\mathrm{CO}$, and $\mathrm{CO}_{2}$, from gasification of biomass and waste streams like sewage sludge and municipal waste (Hammerschmidt et al., 2011, Rokni, 2015) as well as other $C_{1}$ molecules came into focus as interesting substrates for biotechnological applications (Daniell et al., 2012; Bengelsdorf et al., 2013). Bacteria able to grow on hydrogen and carbon monoxide/carbon dioxide as sole energy and carbon source are called acetogens (Diekert and Wohlfarth, 1994). They use a metabolic pathway unique to this class of bacteria (Schuchmann and Müller, 2014) which incorporates two molecules of $\mathrm{CO}$ or $\mathrm{CO}_{2}$ via subsequent reactions into one molecule of acetyl-CoA (Diekert and Wohlfarth, 1994). This pathway is known as Wood-Ljungdahl-pathway or acetyl-CoApathway (Schuchmann and Müller, 2014). Further conversion of acetyl-CoA yields acetate, ethanol, butyrate, butanol, or 2,3butandiol as natural products of this pathway. Of these, the formation of $\mathrm{C}_{2}$-molecules (acetate and ethanol) has the highest energy gain for acetogenic bacteria (Bengelsdorf et al., 2013). Therefore, $\mathrm{C}_{2}$-molecules are the preferred products with reported concentrations of up to $44 \mathrm{~g} / \mathrm{L}$ (Demler and Weuster-Botz, 2011). Reported concentrations for butyrate, butanol and 2,3butanediol are low compared to acetic acid (Neumann et al., 2015). More details about the metabolism of acetogenic bacteria can be found in Schuchmann and Müller (2014) or Bengelsdorf et al. (2013).

Neither are acetogenic bacteria able to produce dicarboxylic acids like malic acid or fumaric acid, as their product spectrum is limited due to energetic reasons, nor are Aspergilli able to use $\mathrm{C}_{1}$ molecules like $\mathrm{CO}$ or $\mathrm{CO}_{2}$ as fermentation substrates. Therefore, this study focuses on broadening the substrate spectrum for production of malic acid or any other biotechnological product beyond glycerol and sugars and simultaneously expanding the product spectrum of syngas fermentation. By sequential coupling of anaerobic syngas fermentation and aerobic malic acid production the substrate spectrum is broadened to syngas, which can be obtained from steel mill off-gas (Köpke et al., 2011) or by gasification of biomass organic wastes and fossil feedstocks (Neumann et al., 2015), forging a completely new and highly innovative path toward the establishment of a biobased economy.

\section{MATERIALS AND METHODS}

\section{Microorganisms and Medium}

If not stated differently all chemicals were purchased from CarlRoth (Germany) or Sigma-Aldrich (Germany).The organism used for the syngas fermentation part of the study was Clostridium ljungdahlii DSM13528 which was kindly provided by the group of Peter Dürre, University of Ulm. Medium used for cultivation of C. ljungdahlii for both flask and bioreactor cultivation was based on Tanner (2007). Medium for maintenance and pre-culture cultivation contained: $20 \mathrm{~g} / \mathrm{L} 2-(\mathrm{N}$ morpholino) ethansulfonic acid (MES), $0.5 \mathrm{~g} / \mathrm{L}$ yeast extract (BD, USA), $2 \mathrm{~g} / \mathrm{L} \mathrm{NaCl}, 2.5 \mathrm{~g} / \mathrm{L} \mathrm{NH}_{4} \mathrm{Cl}, 0.25 \mathrm{~g} / \mathrm{L} \mathrm{KCl}, 0.25 \mathrm{~g} / \mathrm{L} \mathrm{KH}_{2} \mathrm{PO}_{4}$, $0.5 \mathrm{~g} / \mathrm{L} \mathrm{MgSO} 4 \cdot 7 \mathrm{H}_{2} \mathrm{O}, 0.1 \mathrm{~g} / \mathrm{L} \mathrm{CaCl}_{2} \cdot 2 \mathrm{H}_{2} \mathrm{O}, 10 \mathrm{~mL}$ trace element solution (composition see below), $10 \mathrm{~mL}$ vitamin solution (composition see below) and $0.001 \mathrm{~g} / \mathrm{L}$ resazurin and was prepared using strict anaerobic techniques. The $\mathrm{pH}$ was adjusted to 5.9 using $\mathrm{KOH}$ before bottling. Bottles were anaerobized using a gas mixture containing 20 vol- $\%$ carbon dioxide in nitrogen (Air Liquide, France). After autoclaving at $121^{\circ} \mathrm{C}, 1 \mathrm{~g}$ Cysteine$\mathrm{HCl} \cdot \mathrm{H}_{2} \mathrm{O}$ and $10 \mathrm{~g}$ fructose per liter were added. Trace element solution contained: $2 \mathrm{~g} / \mathrm{L}$ nitrilotriacetic acid, $1 \mathrm{~g} / \mathrm{L} \mathrm{MnSO}_{4} \cdot \mathrm{H}_{2} \mathrm{O}$, $0.567 \mathrm{~g} / \mathrm{L} \mathrm{FeSO}_{4} \cdot 7 \mathrm{H}_{2} \mathrm{O}, 0.2 \mathrm{~g} / \mathrm{L} \mathrm{CoCl} 2 \cdot 6 \mathrm{H}_{2} \mathrm{O}$ (Riedel-de Haën, Germany), $0.2 \mathrm{~g} / \mathrm{L} \mathrm{ZnSO}_{4} \cdot 7 \mathrm{H}_{2} \mathrm{O}, 0.02 \mathrm{~g} / \mathrm{L} \mathrm{CuCl}_{2} \cdot 2 \mathrm{H}_{2} \mathrm{O}, 0.02 \mathrm{~g} / \mathrm{L}$ $\mathrm{NiCl}_{2} \cdot 6 \mathrm{H}_{2} \mathrm{O}, 0.02 \mathrm{~g} / \mathrm{L} \quad \mathrm{Na}_{2} \mathrm{MoO}_{4} \cdot 2 \mathrm{H}_{2} \mathrm{O}, 0.02 \mathrm{~g} / \mathrm{L} \mathrm{Na} \mathrm{NeO}_{3} \cdot 5$ $\mathrm{H}_{2} \mathrm{O}$, and $0.022 \mathrm{~g} / \mathrm{L} \mathrm{Na} \mathrm{WO}_{4} \cdot 2 \mathrm{H}_{2} \mathrm{O}$. Vitamin solution used for all anaerobic medium in this work contained: $0.002 \mathrm{~g} / \mathrm{L}$ biotin, $0.002 \mathrm{~g} / \mathrm{L}$ folic acid, $0.01 \mathrm{~g} / \mathrm{L}$ pyridoxine (Alfa Aesar, Germany), 
$0.005 \mathrm{~g} / \mathrm{L}$ thiamine- $\mathrm{HCl}, 0.005 \mathrm{~g} / \mathrm{L}$ riboflavin, $0.005 \mathrm{~g} / \mathrm{L}$ niacin, $0.005 \mathrm{~g} / \mathrm{L}$ Ca-pantothenate, $0.005 \mathrm{~g} / \mathrm{L}$ cobalamin, $0.005 \mathrm{~g} / \mathrm{L}$ 4 -aminobenzoic acid, and $0.005 \mathrm{~g} / \mathrm{L}$ liponic acid (Cayman Chemical, USA). Maintenance cultures were cultivated at $37^{\circ} \mathrm{C}$ without shaking and inoculated every 4 days using the latest maintenance culture.

The A. oryzae DSM1863 strain was received from DSMZ strain collection (Deutsche Sammlung von Mikroorganismen und Zellkulturen, Braunschweig, Germany) and was grown on minimal medium (MM) for Aspergillus species (Barratt et al., 1965): $6 \mathrm{~g} / \mathrm{L} \mathrm{NaNO}_{3}, 0.52 \mathrm{~g} / \mathrm{L} \mathrm{KCl}, 0.52 \mathrm{~g} / \mathrm{L} \mathrm{MgSO}_{4} \cdot 7 \mathrm{H}_{2} \mathrm{O}$, and $1.52 \mathrm{~g} / \mathrm{L} \mathrm{KH}_{2} \mathrm{PO}_{4}$. The $\mathrm{pH}$ was set to 6.5 with $4 \mathrm{M} \mathrm{NaOH}$. $2 \mathrm{~mL}$ of $1000 \times$ Hutner's Trace Elements, $10 \mathrm{~g} / \mathrm{L}$ glucose, and $15 \mathrm{~g} / \mathrm{L}$ agar were added, and the medium was sterilized by autoclaving. $1000 \times$ Hutner's Trace Element solution contained $5 \mathrm{~g} / \mathrm{L} \mathrm{FeSO} \cdot 7 \mathrm{H}_{2} \mathrm{O}, 50 \mathrm{~g} / \mathrm{L}$ EDTA-Na $2,22 \mathrm{~g} / \mathrm{L} \mathrm{ZnSO} \cdot 7 \mathrm{H}_{2} \mathrm{O}$, $11 \mathrm{~g} / \mathrm{L} \mathrm{H}_{3} \mathrm{BO}_{3}, 5 \mathrm{~g} / \mathrm{L} \mathrm{MnCl}_{2} \cdot 4 \mathrm{H}_{2} \mathrm{O}, 1.6 \mathrm{~g} / \mathrm{L} \mathrm{CoCl}_{2} \cdot 6 \mathrm{H}_{2} \mathrm{O}$, $1.6 \mathrm{~g} / \mathrm{L} \mathrm{CuSO}_{4} \cdot 5 \mathrm{H}_{2} \mathrm{O}$, and $1.1 \mathrm{~g} / \mathrm{L}\left(\mathrm{NH}_{4}\right)_{6} \mathrm{Mo}_{7} \mathrm{O}_{24} \cdot 4 \mathrm{H}_{2} \mathrm{O}, \mathrm{pH}$ 6.5 (Barratt et al., 1965). For conidia collection, the fungus was grown on high-salt minimal medium (Song et al., 2001) which additionally contained $22.37 \mathrm{~g} / \mathrm{L} \mathrm{KCl}$. Conidia were harvested with $50 \%$ glycerol solution from plates that were incubated for 5 days at $30{ }^{\circ} \mathrm{C}$ and filtered through Miracloth (Calbiochem). The conidia solution was diluted to a concentration of $10^{7}$ conidia/mL and stored at $-80{ }^{\circ} \mathrm{C}$. Sequential malic acid production was accomplished in a two-step process with a pre-culture and a main culture. The main culture was either the fermentation broth from C. ljungdahlii syngas-fermentation (see above) or main culture medium for fungal malic acid production (Ochsenreither et al., 2014). The pre-culture medium contained $40 \mathrm{~g} / \mathrm{L}$ glucose monohydrate, $4 \mathrm{~g} / \mathrm{L}\left(\mathrm{NH}_{4}\right)_{2} \mathrm{SO}_{4}, 0.75 \mathrm{~g} / \mathrm{L} \mathrm{KH} \mathrm{KO}_{4}, 0.98 \mathrm{~g} / \mathrm{L}$
$\mathrm{K}_{2} \mathrm{HPO}_{4} \cdot 3 \mathrm{H}_{2} \mathrm{O}, 0.1 \mathrm{~g} / \mathrm{L} \mathrm{MgSO} 4 \cdot 7 \mathrm{H}_{2} \mathrm{O}, 0.1 \mathrm{~g} / \mathrm{L} \mathrm{CaCl} \cdot 2 \mathrm{H}_{2} \mathrm{O}$, $5 \mathrm{mg} / \mathrm{L} \mathrm{NaCl}$, and $5 \mathrm{mg} / \mathrm{L} \mathrm{FeSO}_{4} \cdot 7 \mathrm{H}_{2} \mathrm{O}$ and was sterilized by autoclaving for $20 \mathrm{~min}$ at $121{ }^{\circ} \mathrm{C}$. Main culture medium contained $120 \mathrm{~g} / \mathrm{L}$ glucose monohydrate, $1.2 \mathrm{~g} / \mathrm{L}\left(\mathrm{NH}_{4}\right)_{2} \mathrm{SO}_{4}, 0.1$ $\mathrm{g} / \mathrm{L} \mathrm{KH}_{2} \mathrm{PO}_{4}, 0.17 \mathrm{~g} / \mathrm{L} \mathrm{K}_{2} \mathrm{HPO}_{4} \cdot 3 \mathrm{H}_{2} \mathrm{O}, 0.1 \mathrm{~g} / \mathrm{L} \mathrm{MgSO}_{4} \cdot 7 \mathrm{H}_{2} \mathrm{O}$, $0.1 \mathrm{~g} / \mathrm{L} \mathrm{CaCl} 2 \cdot 2 \mathrm{H}_{2} \mathrm{O}, 5 \mathrm{mg} / \mathrm{L} \mathrm{NaCl}$, and $60 \mathrm{mg} / \mathrm{L} \mathrm{FeSO}_{4} \cdot 7 \mathrm{H}_{2} \mathrm{O}$. To keep the $\mathrm{pH}$ above 5.5 during acid production $90 \mathrm{~g}$ per liter $\mathrm{CaCO}_{3}$ were added.

\section{Fermentation Setup and Operation}

Fermentations were carried out in Minifors bench-top stirred tank reactors from Infors-HT (Switzerland) with a total volume of $2.5 \mathrm{~L}$ and a liquid volume of $1.5 \mathrm{~L}$ leaving a $1 \mathrm{~L}$ headspace. Figure 1 shows a basic scheme of the process setup for both anaerobic syngas fermentation and aerobic fungal fermentation.

For anaerobic syngas fermentation with C. ljungdahlii, each bioreactor was equipped with a Pt-100 temperature probe (Infors-HT, Switzerland), pH-probe (Mettler-Toledo, USA.) and an EasyFerm Plus ORP-probe (Hamilton, Switzerland) for measurement and recording of temperature, $\mathrm{pH}$ and redox potential during fermentation. The $\mathrm{pH}$ was regulated to 5.9 by addition of $4 \mathrm{M} \mathrm{KOH}$ solution which was kept under a nitrogen atmosphere to ensure anaerobic conditions. Temperature of the broth was maintained at $37{ }^{\circ} \mathrm{C}$ using the heating block of the bioreactor housing. To prevent foaming, bioreactors were fitted with a foam probe (Infors-HT, Switzerland) using Contraspum A 4050 HAC (Zschimmer und Schwarz, Germany) as an anti-foaming agent. Each bioreactor was equipped with a microsparger for creation of microbubbles to enhance mass transfer between gaseous and aqueous phase (Bredwell and Worden, 1998). The gas flow rate of $20 \mathrm{~mL} / \mathrm{min}$ into the

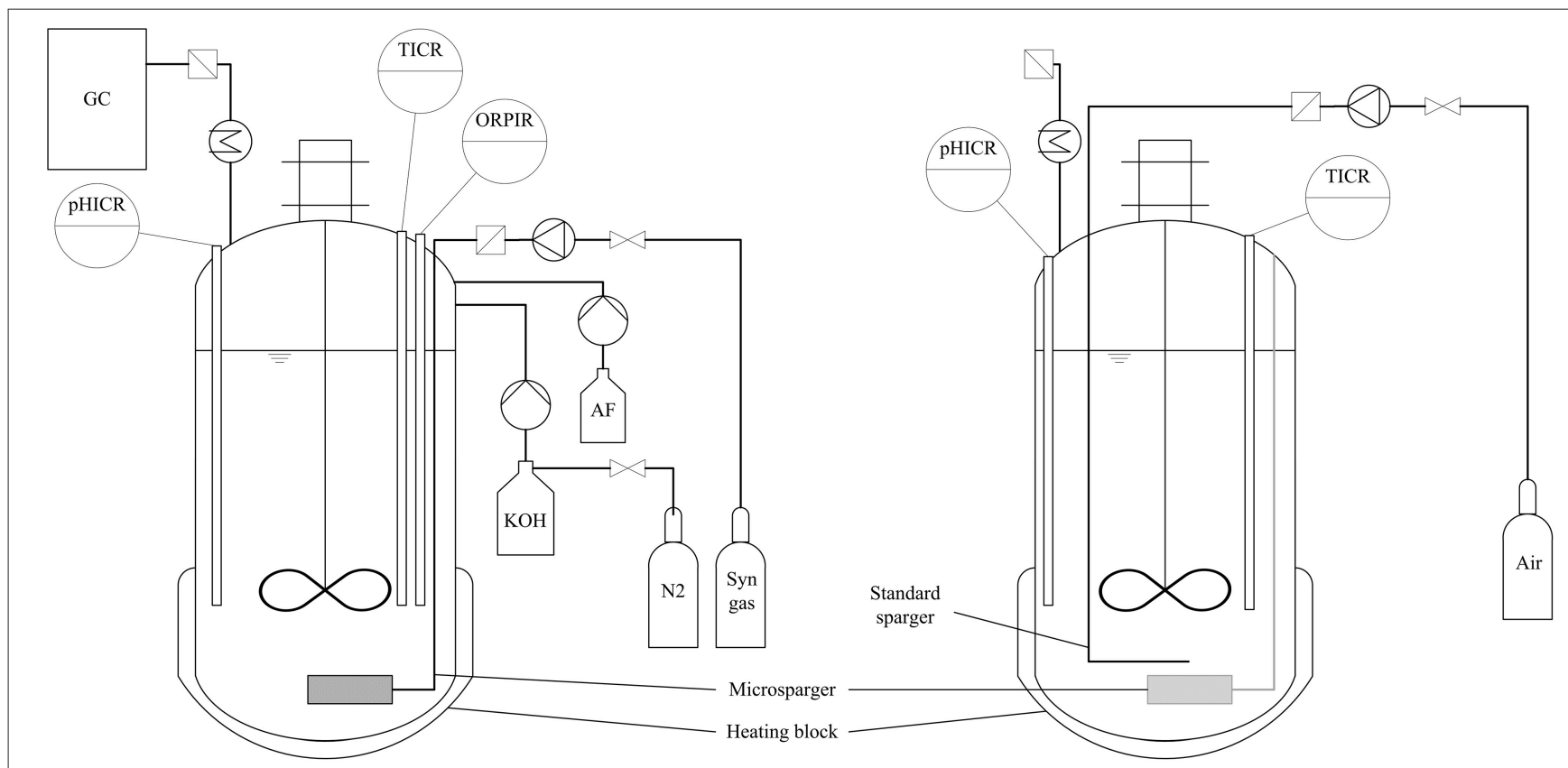

FIGURE 1 | Basic scheme of process setup for anaerobic syngas fermentation (left) and aerobic fungal fermentation (right). pHICR, pH indicate, control and record; TICR, temperature indicate, control and record; ORPICR, ORP indicate, control and record; AF, anti-foam; GC, gas chromatograph. For aerobic fungal fermentation the microsparger had to be turned sideways to make room for the standard sparger. No pH adjustment was conducted during fungal fermentation. 
bioreactors was controlled using red-y smart series massflow-controller (MFC) from Vögtlin Instruments (Switzerland). Composition of the syngas used in this work was 32.5 vol-\% $\mathrm{H}_{2}, 32.5$ vol-\% CO, 16 vol-\% $\mathrm{CO}_{2}$, and 19 vol-\% $\mathrm{N}_{2}$ (Air Liquide, France), mimicking a composition of purified syngas from entrained bed gasification of straw. The headspace of the bioreactor was at atmospheric pressure. Gas-liquid mixing was achieved at $800 \mathrm{rpm}$ using a stirrer setup for vortex formation (Figure 1). No baffles were used. Medium for bioreactor cultivations was prepared under aerobic conditions with the same composition as the maintenance- and pre-culture medium except for fructose which was omitted and cysteine- $\mathrm{HCl}$ which was reduced to $0.53 \mathrm{~g} / \mathrm{L}$. After autoclaving at $121{ }^{\circ} \mathrm{C}$ for $20 \mathrm{~min}$ the redox potential of the medium was lowered to about $-200 \mathrm{mV}$ by sparging with syngas and addition of the above stated amount of cysteine-HCl. Pre-cultures of C. ljungdahlii for reactor experiments were grown for $48 \mathrm{~h}$ with fructose as carbon and energy source. Bioreactors were inoculated with $10 \%$ of their final volume using sterile silicon tubing with cannulas at both ends. After $96 \mathrm{~h}$ of growth on syngas the broth was either harvested for preliminary tests with $A$. oryzae or switched to aerobic conditions for the main coupling experiment.

For A. oryzae fermentation, $100 \mathrm{~mL}$ pre-culture medium was filled in $500 \mathrm{~mL}$ baffled shake flasks and inoculated with $2 \times 10^{7}$ conidia. The culture was incubated for ca. $24 \mathrm{~h}$ at $30{ }^{\circ} \mathrm{C}$ and $100 \mathrm{rpm}$ in a rotary shaker. Fungal pellets were washed twice with distilled water to remove pre-culture medium components before inoculation of the main culture. For shake flask cultivation, $100 \mathrm{~mL}$ of main-culture was transferred to $500 \mathrm{~mL}$ baffled shake flasks and mixed with $9 \mathrm{~g}$ sterile $\mathrm{CaCO}_{3}$. The flasks were inoculated with 10 vol- $\%$ of washed pre-culture and incubated at $120 \mathrm{rpm}$ and $32{ }^{\circ} \mathrm{C}$ for 7 days. Fermentation in bioreactor was done in small scale bioreactor Minifors (vessel volume 2.5 L; Infors, Switzerland). To generate the conditions for malic acid production, some modifications of the reactor were necessary. The antifoam probe was replaced by a standard sparger to avoid clogging of the microsparger by the fungus and the redox potential probe was removed to enable inoculation with fungal preculture (fungal biomass of two preculture flasks) and $\mathrm{CaCO}_{3}$ was added ( $90 \mathrm{~g}$ per bioreactor). The microsparger was twisted sideways. Before inoculation, aeration was changed from syngas to air for $\sim 30 \mathrm{~min}$ to remove all CO in solution and $200 \mu \mathrm{L}$ of antifoam reagent (Contraspum A 4050 HAC, Zschimmer und Schwarz) was added. After inoculation, the fermentation took place at $35{ }^{\circ} \mathrm{C}$ with an aeration rate of $0.6 \mathrm{~L} / \mathrm{min}$ and a stirrer speed of $300 \mathrm{rpm}$. Approximately every $24 \mathrm{~h} 5 \mathrm{~mL}$ samples were taken.

\section{Analytical Methods}

Measurement of the off-gas composition of the syngas fermentation was conducted via a GC-2010 Plus AT gas chromatograph (GC) system (Shimadzu, Japan) equipped with a customized column setup using a ShinCarbon ST 80/100 Column ( $2 \mathrm{~m} \times 0.53 \mathrm{~mm}$ ID, Restek, Germany) and a Rtx-1 capillary column $(1 \mu \mathrm{m}, 30 \mathrm{~m} \times 0.25 \mathrm{~mm}$ ID, Restek, Germany). The installed detector was a thermal conductivity detector with helium as the carrier gas. Column flow rate was $3 \mathrm{~mL} / \mathrm{min}$ and oven temperature was kept at $40^{\circ} \mathrm{C}$ for $3 \mathrm{~min}$ followed by a ramp of $35^{\circ} \mathrm{C} / \mathrm{min}$. Total analysis time was $7.5 \mathrm{~min}$. The off-gas line of every bioreactor was connected to the GC using a stream selector which, after each measurement, automatically selected the next bioreactor and thus enabled for automated off-gas analysis. Since the syngas in this work contained nitrogen and C. ljungdahlii is not able to use $\mathrm{N}_{2}$ as a nitrogen source we calculated the flow rate in the off-gas line $\left(\dot{V}_{\text {off }(t)}\right)$ according to

$$
\begin{aligned}
\dot{V}_{\text {off }(t)} & =\frac{\varphi_{\mathrm{N}_{2}, \text { in }}}{\varphi_{\mathrm{N}_{2}, \text { off }}} \dot{V}_{\text {in }(t)} . \\
\dot{V}_{\mathrm{off}(t)} & =\text { flowrate in off-gas line, } \mathrm{mL} / \mathrm{min} \\
\varphi_{\mathrm{N}_{2}, \text { in }} & =\text { volume ratio of nitrogen in ingoing gas stream,- } \\
\varphi_{\mathrm{N}_{2}, \text { off }} & =\text { volume ratio of nitrogen in off-gas,- } \\
\dot{V}_{\mathrm{in}(t)} & =\text { flowrate of ingoing gas, } \mathrm{mL} / \mathrm{min}
\end{aligned}
$$

Using Equation (1), the ideal gas law and conditions in the lab ( $T=298.15 \mathrm{~K} ; p=1.013 \mathrm{bar}$ ), it was possible to calculate the amount of substance flow rate $\left(\dot{n}_{\mathrm{i}}\right)$ in $\mathrm{mmol} / \mathrm{min}$ for each component $i$ in the off-gas to

$$
\begin{aligned}
\dot{n}_{\mathrm{i}}(t) & =0.0409 \frac{\mathrm{mmol}}{\mathrm{mL}} \varphi_{\mathrm{i}, \text { off }} \dot{V}_{\mathrm{off}(t)} . \\
\dot{n}_{\mathrm{i}(t)} & =\text { amount of substance flow rate of substance } \mathrm{i}, \mathrm{mmol} / \mathrm{min} \\
\varphi_{\mathrm{i}, \text { off }} & =\text { volume ratio of substance } \mathrm{i} \text { in off-gas, }-
\end{aligned}
$$

Equation (3) calculates the amount of substance balance $\left(\Delta \dot{n}_{\mathrm{i}}\right)$ between off-gas and gas inlet.

$$
\begin{aligned}
\Delta \dot{n}_{\mathrm{i}(t)}= & \dot{n}_{\mathrm{i}, \text { in }(t)}-\dot{n}_{\mathrm{i}, \text { off }(t)} \\
\Delta \dot{n}_{\mathrm{i}(t)}= & \text { amount of substance balance for substance } \mathrm{i}, \\
& \mathrm{mmol} / \mathrm{min} \\
\dot{n}_{\mathrm{i}, \text { in }(t)=} & \text { amount of substance flow rate of } \mathrm{i} \text { in ingoing gas } \\
& \text { stream, mmol/min } \\
\dot{n}_{\mathrm{i}, \text { off }(t)=} & \text { amount of substance flow rate of } \mathrm{i} \text { in off-gas, } \\
& \text { mmol/min }
\end{aligned}
$$

Since there is no other sink or source for $\mathrm{H}_{2}, \mathrm{CO}$, and $\mathrm{CO}_{2}$ other than the metabolism of C. ljungdahlii $\Delta \dot{n}_{\mathrm{i}}$ equates to the uptakeor release rate of those molecules by the organisms.

To get the actual amount of $\mathrm{CO}$ that has gone into products and biomass it was necessary to account for $\mathrm{CO}$ that has been converted to $\mathrm{CO}_{2}$ by $C$. liungdahlii and left the bioreactor. Therefore, the absolute value of $\Delta \dot{n}_{\mathrm{CO}_{2}}$ was subtracted from $\Delta \dot{n}_{\mathrm{CO}}$ if $\Delta \dot{n}_{\mathrm{CO}_{2}}<0$ was true. Since $\dot{n}_{\mathrm{i}, \text { off }}$ was only determined in set intervals, linear interpolation of $\Delta \dot{n}_{\mathrm{i}}$ between two points of measurement gave better approximation of the developing of $\Delta \dot{n}_{\mathrm{i}}$. The total consumed amount of substance in the bioreactor at each time $\left(n_{\mathrm{i}, \mathrm{R}(t)}\right)$, that has gone into products and biomass, was then calculated by integration of the linear interpolation. This 
resulted in Equation (4).

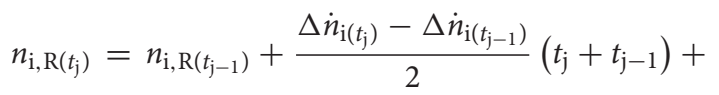

$$
\begin{aligned}
& \left(\Delta \dot{n}_{\mathrm{i}\left(t_{j-1}\right)}-\frac{\Delta \dot{n}_{\mathrm{i}\left(t_{\mathrm{j}}\right)}-\Delta \dot{n}_{\mathrm{i}\left(t_{j-1}\right)}}{\left(t_{\mathrm{j}}-t_{\mathrm{j}-1}\right)} t_{\mathrm{j}-1}\right)\left(t_{\mathrm{j}}-t_{\mathrm{j}-1}\right)
\end{aligned}
$$

The complete derivation of equation (4) can be found in data sheet 1 in the supplemental data section. Dividing $n_{\mathrm{i}, \mathrm{R}(t)}$ by the total amount of substance $i$ that has gone into the bioreactor gave the ratio of fixation for each substance in percent as shown by Equation (5).

$$
\begin{aligned}
E_{\mathrm{i}(t)} & =100 \frac{n_{\mathrm{i}, \mathrm{R}(t)}}{t \dot{n}_{\mathrm{i}, \mathrm{in}(t)}} \\
E_{\mathrm{i}(t)} & =\text { ratio of fixation for substance } \mathrm{i}
\end{aligned}
$$

Liquid samples of $2 \mathrm{~mL}$ were collected every $2 \mathrm{~h}$ during the day. No samples were taken at night. Before the collection of a single liquid sample $3 \mathrm{~mL}$ of reactor broth were taken and discarded to account for the dead volume of the sampling line. Cell concentrations were determined using an Ultrospec1100pro spectrophotometer (Amersham Bioscience, USA) at a wavelength of $600 \mathrm{~nm}$. Therefore, the optical density (OD) of $1 \mathrm{~mL}$ of a liquid sample was measured, then cells were removed via centrifugation at $16100 \times \mathrm{g}$ for $10 \mathrm{~min}$ and OD of the supernatant was measured. The difference of both values gave the $\mathrm{OD}$ of the sample. This procedure was necessary because $\mathrm{OD}$ values of the supernatant changed during fermentation. At measured OD $>0.45$ the OD exceeded the linear range of the $\mathrm{OD} /$ cell mass relation and samples had to be diluted using $9 \mathrm{~g} / \mathrm{L} \mathrm{NaCl}$ solution. For correlation between $\mathrm{OD}$ and bio dry mass (BDM) the BDM at the end of the syngas fermentation was determined in duplicates. Therefore, $60 \mathrm{~mL}$ of fermentation broth were collected and transferred into pre-weight, dry screwing cap reaction tubes $(30 \mathrm{~mL}$ each). The tubes were centrifuged at $4816 \times \mathrm{g}$ and $4{ }^{\circ} \mathrm{C}$ for $15 \mathrm{~min}$. The supernatant was discarded and pellets were washed two times with a $9 \mathrm{~g} / \mathrm{L} \mathrm{NaCl}$ solution. The tubes with the washed pellets were dried at $60^{\circ} \mathrm{C}$ for $48 \mathrm{~h}$ before they were weighted again and the BDM was calculated. The quotient of BDM and OD at the end of the syngas fermentation gave the BDM/OD correlation coefficient of $0.139 \pm 0.041 \mathrm{~g} / \mathrm{L}$. Liquid samples were centrifuged to remove cells and the supernatant was stored frozen at $-20^{\circ} \mathrm{C}$ and used for further off-line analysis.

Measurement of fructose was done using an enzymatic D-fructose/D-glucose assay of Roche Yellow line (HoffmannLa Roche, Switzerland) following the instructions delivered with the assay. Concentrations of ethanol and acetic acid of samples containing fructose were also measured with respective enzymatic assays from Roche Yellow line following their instructions. Samples which were collected after complete consumption of leftover fructose from the pre-cultures were analyzed for ethanol and acetic acid using a 6890N GC (Agilent,
USA) equipped with auto-sampler, ROTICAP-FFAP capillary column $(0.5 \mu \mathrm{m}, 30 \mathrm{~m} \times 0.32 \mathrm{~mm}$ ID, Carl-Roth, Germany) and flame ionization detector. Carrier gas was helium with a pressure of 1 bar and split ratio was 7.5:1. Analytical standard mixture consisted of $5 \mathrm{mM}$ ethanol, $5 \mathrm{mM}$ sodium acetate, and $9.09 \mathrm{mM}$ isobutanol in $0.18 \mathrm{M} \mathrm{HCl}$. Samples were prepared by acidifying $500 \mu \mathrm{L}$ of sample with $50 \mu \mathrm{L}$ internal standard solution consisting of $100 \mathrm{mM}$ isobutanol in $2 \mathrm{M} \mathrm{HCl}$. Analysis was conducted by injecting $1 \mu \mathrm{L}$ of sample or standard. The temperature profile of the column oven started with initial $60^{\circ} \mathrm{C}$ for $2 \mathrm{~min}$ followed by a temperature ramp of $10^{\circ} \mathrm{C} / \mathrm{min}$ up to an end temperature of $180^{\circ} \mathrm{C}$. Total analysis time was $20 \mathrm{~min}$.

The concentrations of malic and acetic acid during cultivation with $A$. oryzae were quantified with HPLC. Fermentation broth samples were pretreated and analyzed as described in Ochsenreither et al. (2014). To resolve as calcium salt precipitated organic acids, $1 \mathrm{~mL}$ of well-mixed sample was mixed with $1 \mathrm{~mL}$ of $3 \mathrm{M} \mathrm{H}_{2} \mathrm{SO}_{4}$ and $3 \mathrm{~mL}$ of distilled water and incubated at $80^{\circ} \mathrm{C}$ for $20 \mathrm{~min}$. One milliliter of the mixture was transferred to a $1.5 \mathrm{~mL}$ Eppendorf tube and centrifuged in a bench top centrifuge for $5 \mathrm{~min}$ at $20,000 \times \mathrm{g}$. The supernatant was used for HPLC analysis. The analysis was performed at $30{ }^{\circ} \mathrm{C}$ with a standard HPLC device (Agilent 1100 Series, Agilent, USA) prepared with a $15 \mathrm{~cm}$ reversed phase column (Synergi ${ }^{\mathrm{TM}} 4 \mu \mathrm{m}$ Fusion-RP 80 Å, LC Column $150 \times 4.6 \mathrm{~mm}$, Phenomenex, Germany). Mobile phase solution A was $100 \%$ methanol, and solution B was $20 \mathrm{mM}$ $\mathrm{KH}_{2} \mathrm{PO}_{4}, \mathrm{pH} 2.5$. The flow rate was $1 \mathrm{~mL} / \mathrm{min}$ and a gradient was used for the separation of organic acids: $0-0.5 \mathrm{~min} 100 \%$ eluent $B, 0.5-10$ min increase of eluent $A$ from 0 to $10 \%, 10-12 \mathrm{~min}$ a decrease of eluent $\mathrm{A}$ from 10 back to $0 \%$, and $12-14 \mathrm{~min}$ again $100 \%$ eluent $\mathrm{B}$. The injection volume was $10 \mu \mathrm{L}$ and the detection was performed by a UV detector at $220 \mathrm{~nm}$. Malic acid standard was purchased from Sigma-Aldrich (Germany), acetic acid standard from Carl-Roth (Germany). Both were used for peak identification and calibration. The linear detection range went from $0.1 \mathrm{~g} / \mathrm{L}$ to $5 \mathrm{~g} / \mathrm{L}$ malic acid and acetic acid.

\section{RESULTS}

\section{Preliminary Experiments Optimization of Bioreactor Medium for Sequential Production of Malic Acid from Acetic Acid}

Since malic acid is produced by $A$. oryzae only under nitrogen limited conditions (Knuf et al., 2013) it was necessary to reduce the ammonia content of the medium to ensure nitrogen limitation after syngas fermentation. Initial cultivations, using the above mentioned medium for syngas fermentation, were conducted to determine the amount of ammonia consumed by C. ljungdahlii during $96 \mathrm{~h}$ of growth on synthesis gas (see Table 1). Based on the consumed amount of ammonia, the $\mathrm{NH}_{4} \mathrm{Cl}$ content of the medium for all following precultures and bioreactor experiments was reduced to $0.33 \mathrm{~g} / \mathrm{L}$. Ion chromatography for $\mathrm{NH}_{4}^{+}$-detection was kindly conducted by the section for Bioprocess Engineering of the Institute of Process Engineering in Life Sciences, KIT. Results of medium optimization and preliminary cultivations with $\mathrm{NH}_{4}$-reduced medium are shown in Table 1. Measurement of ammonia 
TABLE 1 | Results of preliminary experiments with C. ljungdahlii growing with syngas as sole carbon source.

\begin{tabular}{|c|c|c|c|c|c|c|c|c|c|}
\hline Medium & $\begin{array}{c}c_{\mathrm{NH}_{4}} \mathrm{Cl} \\
\mathrm{g} / \mathrm{L}\end{array}$ & $\begin{array}{c}c_{\mathrm{BDM}} \\
\mathrm{g} / \mathrm{L}\end{array}$ & $\begin{array}{c}\boldsymbol{c}_{\text {acetic acid }} \\
\mathrm{g} / \mathrm{L}\end{array}$ & $\begin{array}{c}c_{\text {EtOH }} \\
\mathrm{g} / \mathrm{L}\end{array}$ & $\begin{array}{c}\Delta c_{\mathrm{NH}_{4} \mathrm{Cl}} \\
\mathrm{g} / \mathrm{L}\end{array}$ & $\begin{array}{c}c_{\mathrm{H}_{2}, \mathrm{R}} \\
\mathrm{mol} / \mathrm{L}\end{array}$ & $\begin{array}{l}c_{\mathrm{CO}, \mathrm{R}} \\
\mathrm{mol} / \mathrm{L}\end{array}$ & $\begin{array}{c}\mathrm{C}_{\mathrm{CO}_{2}, \mathrm{R}} \\
\mathrm{mol} / \mathrm{L}\end{array}$ & $\begin{array}{c}Y_{\mathrm{P} / \mathrm{S}} \\
\mathrm{g} / \mathrm{g}\end{array}$ \\
\hline Syngas fermentation ${ }^{a}$ & 2.5 & $0.76 \pm 0.29$ & $15.27 \pm 1.68$ & $0.57 \pm 0.58$ & $0.39 \pm 0.06$ & $0.75 \pm 0.04$ & $0.77 \pm 0.05$ & $0.01 \pm 0.04$ & $0.68 \pm 0.05$ \\
\hline $\mathrm{NH}_{4}$-reduced ${ }^{\mathrm{b}}$ & 0.33 & $0.45 \pm 0.14$ & $17.08 \pm 2.28$ & $1.14 \pm 0.77$ & $\mathrm{~N} / \mathrm{A}$ & $0.64 \pm 0.05$ & $0.74 \pm 0.04$ & $-0.09 \pm 0.13$ & $0.67 \pm 0.04$ \\
\hline
\end{tabular}

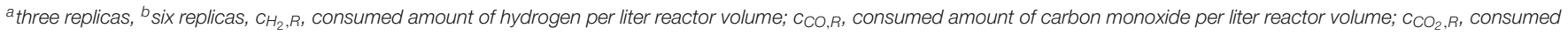
amount of carbon dioxide per liter reactor volume, N/A: not available.

concentration after $96 \mathrm{~h}$ of syngas fermentation using $\mathrm{NH}_{4}$ reduced medium was not possible due to high amounts of potassium ions in the broth.

After $96 \mathrm{~h}$ of fermentation on syngas using syngas fermentation medium (see above) with $2.5 \mathrm{~g} / \mathrm{L}$ ammonia chloride, C. ljungdahlii consumed $386.7 \mathrm{mg} / \mathrm{L}$ ammonia. Nevertheless, fermentation under nitrogen reduced conditions yielded an average of $17.08 \mathrm{~g} / \mathrm{L}$ acetic acid and $1.14 \mathrm{~g} / \mathrm{L}$ ethanol compared to $15.27 \mathrm{~g} / \mathrm{L}$ acetic acid and $0.57 \mathrm{~g} / \mathrm{L}$ ethanol when C. ljungdahlii was cultivated with an excess of ammonia. In ammonia rich medium $C$. ljungdahlii consumed $0.75 \mathrm{~mol} / \mathrm{L}$ of hydrogen and $0.77 \mathrm{~mol} / \mathrm{L}$ of carbon monoxide and in $\mathrm{NH}_{4}$ reduced medium they consumed $0.64 \mathrm{~mol} / \mathrm{L}$ of hydrogen and $0.74 \mathrm{~mol} / \mathrm{L}$ of carbon monoxide. The values for consumed carbon dioxide were around zero for all fermentations in syngas fermentation medium with an average of $0.01 \mathrm{~mol} / \mathrm{L}$ whereas in $\mathrm{NH}_{4}$-reduced medium in some cultivations the bacteria released $\mathrm{CO}_{2}$ to the off-gas, thus the negative mean value of $-0.09 \mathrm{~mol} / \mathrm{L}$. For both medium types the ratio of products (acetic acid and ethanol) to consumed substrates $\left(Y_{\mathrm{P} / \mathrm{S}}\right)$ is roughly the same, with averages of $0.68 \mathrm{~g} / \mathrm{g}$ for syngas medium and $0.67 \mathrm{~g} / \mathrm{g}$ for $\mathrm{NH}_{4}$-reduced medium.

\section{Preliminary Experiment for Fungal Fermentation}

Large quantities of organic acids are produced by certain fungi generally under nitrogen limiting conditions and a simultaneous excess of carbon source. For the production of malic acid with $A$. oryzae these requirements are met in a special production medium as published by Battat et al. (1991). However, this production medium is considerably different from the syngas fermentation medium, a general microbial cultivation medium. Therefore, preliminary experiments were conducted to determine the suitability of acetic acid and ethanol as carbon source, which was never shown before, and the influence of other medium ingredients on malic acid production. These experiments are summarized in Table 2.

\section{Evaluation of Carbon Source and Medium Components}

Influence of major medium components on malic acid production was evaluated in shake flask experiments and fermentation experiments in bioreactors as indicated. The biggest differences of the established process were the carbon source and the nitrogen concentration. It could be shown that acetic acid is an appropriate carbon source for malic acid production in established malic acid production medium with an $Y_{\mathrm{P} / \mathrm{S}}$ of

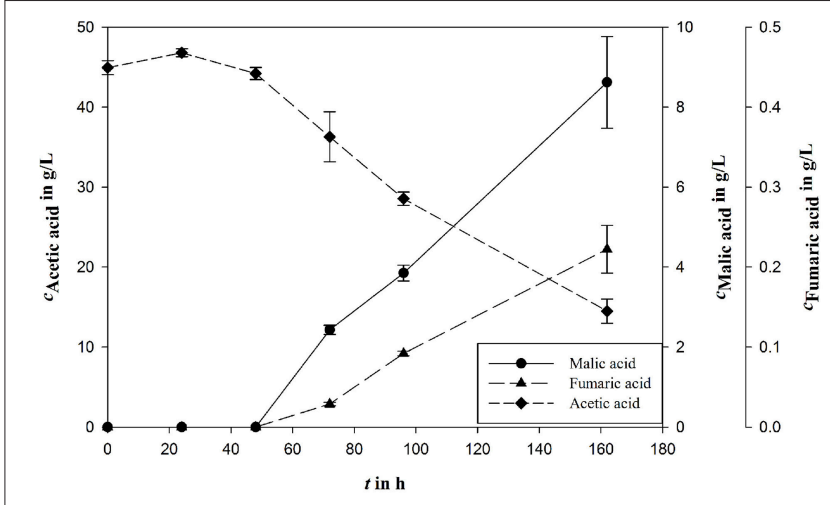

FIGURE 2 | Malic acid production ( $c_{\text {Malic acid }}$ ) using acetic acid ( $\left.c_{\text {Acetic } \text { acid }}\right)$ as carbon source in fungal organic acid production medium. Fumaric acid ( $c_{\text {Fumaric acid }}$ ) is the most important side product during $A$. oryzae fermentation. All concentrations are given as average of three independent experiments \pm standard deviation.

$0.28 \mathrm{~g} / \mathrm{g}$ and a final product concentration of $8.62 \pm 1.15 \mathrm{~g} / \mathrm{L}$ (Figure 2).

The most important byproduct of syngas fermentation is ethanol. Various concentrations of both, acetate and ethanol, could be achieved in different fermentations. To analyze the influence on or the suitability of these molecules as substrates for malic acid production, ethanol was added to production medium. With a yield of $0.55 \mathrm{~g} / \mathrm{g}$ the acetic acid/ethanol-approach reached a final product concentration of $11.68 \pm 1.27 \mathrm{~g} / \mathrm{L}$ (Table 2 ). When ethanol was used as sole carbon source, acid production was not detected. In the second round of experiments the reduction agents cysteine and sodium sulfide were tested. These agents are used during syngas fermentation to reduce contaminating oxygen. Because cysteine is also a potential nitrogen source for $A$. orzyae, tests of the effects on malic acid production are necessary. The results showed a minor influence of the preferred reduction agent cysteine with a final malic acid concentration of $44.2 \pm$ $5.85 \mathrm{~g} / \mathrm{L}\left(Y_{\mathrm{P} / \mathrm{S}}\right.$ of $\left.0.64 \mathrm{~g} / \mathrm{g}\right)$, as well as the alternative reduction agent sodium sulfide with a $Y_{\mathrm{P} / \mathrm{S}}$ of $0.65 \mathrm{~g} / \mathrm{g}(54.04 \pm 14.16 \mathrm{~g} / \mathrm{L})$ compared to the control approach, where no modifications were done, with $47.84 \pm 3.49 \mathrm{~g} / \mathrm{L}$ where a higher $Y_{\mathrm{P} / \mathrm{S}}$ of $0.8 \mathrm{~g} / \mathrm{g}$ could be achieved (Table 2).

It could be shown that the reduction agents are not problematic and acetic acid is an appropriate carbon source for malic acid production. The syngas fermentation medium, which has a significant different composition compared to the malic acid production medium, was a further challenge. Especially the initial ammonium concentration proved to be 
TABLE 2 | Results of preliminary experiments with $A$. oryzae regarding the influence of different medium components and carbon sources on malic acid production.

\begin{tabular}{|c|c|c|c|c|}
\hline Medium & $\begin{array}{l}c_{\text {Carbon source }} \\
g / L\end{array}$ & Modification/Pretreatment & $\begin{array}{c}c_{\text {Malic acid }} \\
g / L\end{array}$ & $\begin{array}{l}Y_{\mathrm{P} / \mathrm{S}}^{\mathrm{b}} \\
\mathrm{g} / \mathrm{g}\end{array}$ \\
\hline Organic acid production medium ${ }^{\mathrm{a}}$ & Glucose 109 & - & $47.84 \pm 3.49$ & 0.8 \\
\hline Organic acid production medium & Glucose 109 & $0.533 \mathrm{~g} / \mathrm{L}$ Cysteine & $44.2 \pm 5.85$ & 0.64 \\
\hline Organic acid production medium & Glucose 109 & $0.533 \mathrm{~g} / \mathrm{L}$ Sodium sulfide & $54.04 \pm 14.16$ & 0.65 \\
\hline Organic acid production medium & Acetic acid 50 & Exchange of carbon source & $8.62 \pm 1.15$ & 0.28 \\
\hline Organic acid production medium & Acetic acid, ethanol 33.33, 16.66 & Exchange of carbon source & $11.68 \pm 1.27$ & 0.55 \\
\hline Organic acid production medium & Ethanol 50 & Exchange of carbon source & 0 & 0 \\
\hline Syngas fermentation mediuma & Acetic acid 50 & Exchange of carbon source & $2.69 \pm 0.81$ & 0.09 \\
\hline Syngas fermentation medium & Acetic acid 50 & Exchange of carbon source, without ammonium & $4.11 \pm 0.50$ & 0.37 \\
\hline Syngas fermentation medium: fermented & Acetic acid $9.80 \pm 0.21$ & Removal of C. ljungdahlii biomass & 0 & 0 \\
\hline Syngas fermentation medium: fermented & Acetic acid $15.84 \pm 1.55$ & Reduced ammonium & $4.34 \pm 0.10$ & 0.27 \\
\hline Syngas fermentation medium: fermented & Acetic acid $8.88 \pm 3.42$ & Reduced ammonium Removal of $C$. ljungdahlii biomass & 0 & 0 \\
\hline
\end{tabular}

${ }^{a}$ control approach, ${ }^{b}$ yield is given after $168 \mathrm{~h}$ cultivation $\left(Y_{P / S}\right)$.

All concentrations are given as average of three independent experiments \pm standard deviation.

problematic as ammonium was not completely consumed during syngas fermentation, so that considerable amounts of ammonium remained for the subsequent fungal fermentation medium. Therefore, to prove if syngas fermentation medium is in general suitable for malic acid production, fungal cultivations in shake flasks with normal concentration and without nitrogen were conducted. Syngas fermentation medium was mixed, autoclaved and enriched with acetic acid as carbon source. Normal ammonium concentration leads to a final malic acid concentration of $2.69 \pm 0.81 \mathrm{~g} / \mathrm{L}$ with a yield of $0.09 \mathrm{~g} / \mathrm{g}$. If no nitrogen source was added $4.11 \pm 0.50 \mathrm{~g} / \mathrm{L}$ and a yield of $0.37 \mathrm{~g} / \mathrm{g}$ could be achieved (Table 2). Therefore, the syngas fermentation medium is a suitable medium for malic acid production, but nitrogen concentration must be limited to a minimum level.

However, in the sequential mixed culture fermentation, the syngas fermentation medium might possibly undergo unknown modifications as a result of Clostridia cultivation. To analyze the effects to the A. oryzae fermentation, an authentic already fermented medium was used including Clostridia-produced acetic acid. On the one hand, the medium containing biomass is a possible nitrogen source; on the other hand biomass could contain some important medium ingredients. To test the influence of biomass on malic acid production, bacterial biomass was either removed by centrifugation or left inside in nitrogen rich or reduced medium. For the first experiments in the bioreactor, a nitrogen rich medium was used. To reduce the nitrogen concentration, biomass was removed by centrifugation. In this approach, no malic acid production could be measured. Further tests in shake flasks were done with ammonium reduced medium, with either removed or not removed biomass. With microbial biomass a malic acid concentration of $4.34 \pm 0.10 \mathrm{~g} / \mathrm{L}$ was produced from $15.84 \pm 1.55 \mathrm{~g} / \mathrm{L}$ acetic acid corresponding to a yield of $0.27 \mathrm{~g} / \mathrm{g}$ (Figure 3 ). The removal of microbial biomass prevented product formation.

Because initial shake flask experiments were promising, the sequential mixed culture approach was tested under realistic conditions, i.e., syngas fermentation followed by fungal fermentation without medium removal and/or delay in between.

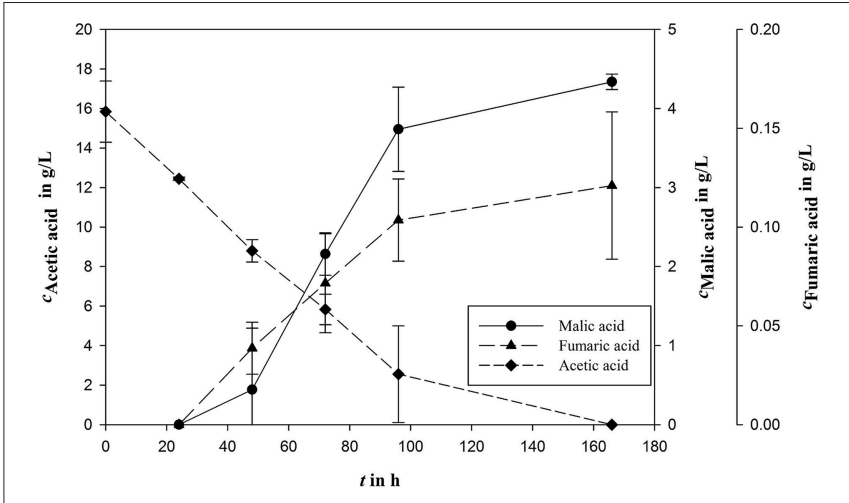

FIGURE 3 | Malic acid production ( $c_{\text {Malic acid }}$ ) using acetic acid $\left(c_{\text {Acetic acid }}\right)$ as carbon source in fermented syngas fermentation medium. Fumaric acid ( $c_{\text {Fumaric acid }}$ ) is the most important side product during $A$. oryzae fermentation. All concentrations are given as average of three independent experiments \pm standard deviation.

\section{Coupling Experiment for Sequential Production of Malic Acid from Acetic Acid} Syngas Fermentation

For the main experiment, $\mathrm{NH}_{4}$-reduced medium was used for syngas fermentation to ensure nitrogen limited conditions after $96 \mathrm{~h}$. Syngas was delivered into the broth with a starting rate of $20 \mathrm{~mL} / \mathrm{min}$ and was increased after $42 \mathrm{~h}$ to $25 \mathrm{~mL} / \mathrm{min}$. Figure 4 shows mean values for offline measured concentrations of biomass, fructose, acetate, and ethanol as well as for online measured values for amount of substance flow rates of hydrogen, carbon monoxide, and carbon dioxide in the off-gas.

In the beginning of the experiment, fructose concentration and amount of carbon monoxide in the off-gas decreased constantly until fructose was not detectable anymore at $19.5 \mathrm{~h}$. Biomass concentration continuously increased until $49 \mathrm{~h}$ and stayed at $0.3 \mathrm{~g} / \mathrm{L}$ for the rest of the fermentation. Acetate and Ethanol concentrations increased to maximum mean values at the end of the syngas fermentation of $15.9 \mathrm{~g} / \mathrm{L}$ and $2.0 \mathrm{~g} / \mathrm{L}$, 


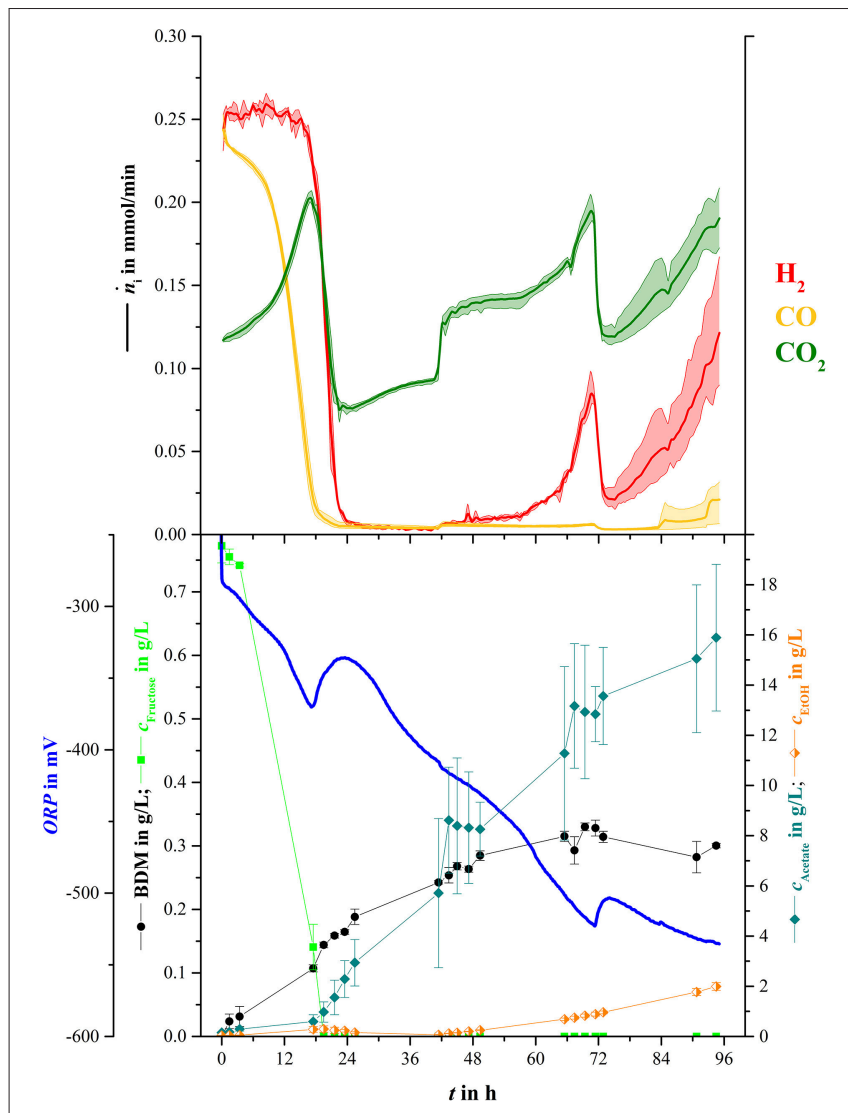

FIGURE 4 | Mean online and offline values for syngas fermentation part of sequential mixed culture (three replicas). Upper part: Average amount of substance flow rates for hydrogen (red), carbon monoxide (yellow), and carbon dioxide (green) in the off-gas. The lightly colored areas around the average lines show minimum and maximum variance between bioreactors. Bottom part: Average values for ORP (blue line), BDM (black dots), fructose concentration (light green squares), acetate concentration (blue-green diamonds), and ethanol concentration (orange half-filled diamonds).

respectively. Similar to the decrease of carbon monoxide in the off-gas, carbon dioxide increased up to a local maximum of $0.2 \mathrm{mmol} / \mathrm{min}$ after $17.3 \mathrm{~h}$ of cultivation, then dropped to an average of $0.07 \mathrm{mmol} / \mathrm{min}$ when hydrogen consumption started. Hydrogen off-gas values stayed as low as $0.005 \mathrm{mmol} / \mathrm{min}$ and slightly increased when the rate of ingoing syngas was increased. After about $47 \mathrm{~h}$ the hydrogen content in the off-gas started to increase. In contrast to hydrogen and carbon dioxide, carbon monoxide values in the off-gas stayed low until $83.0 \mathrm{~h}$ when they started to increase until the end of the fermentation. The decreases of gas flow rates at $71.0 \mathrm{~h}$ were due to reduction of the ingoing gas stream to $20 \mathrm{~mL} / \mathrm{min}$.

For better illustration, the consumed amount of substance $\left(n_{\mathrm{i}, \mathrm{R}}\right)$ of each syngas component (except nitrogen) and the rates $\left(\Delta \dot{n}_{\mathrm{i}}\right)$ of consumption were calculated over the course of this fermentation. Figure 5 shows the results of those calculations.

The amount of consumed carbon monoxide increased continuously from inoculation and reached an average maximum of $0.84 \mathrm{~mol} / \mathrm{L}$. This equals to $79.6 \%$ of the total $\mathrm{CO}$ that went into the bioreactor (dotted yellow line). The amount of

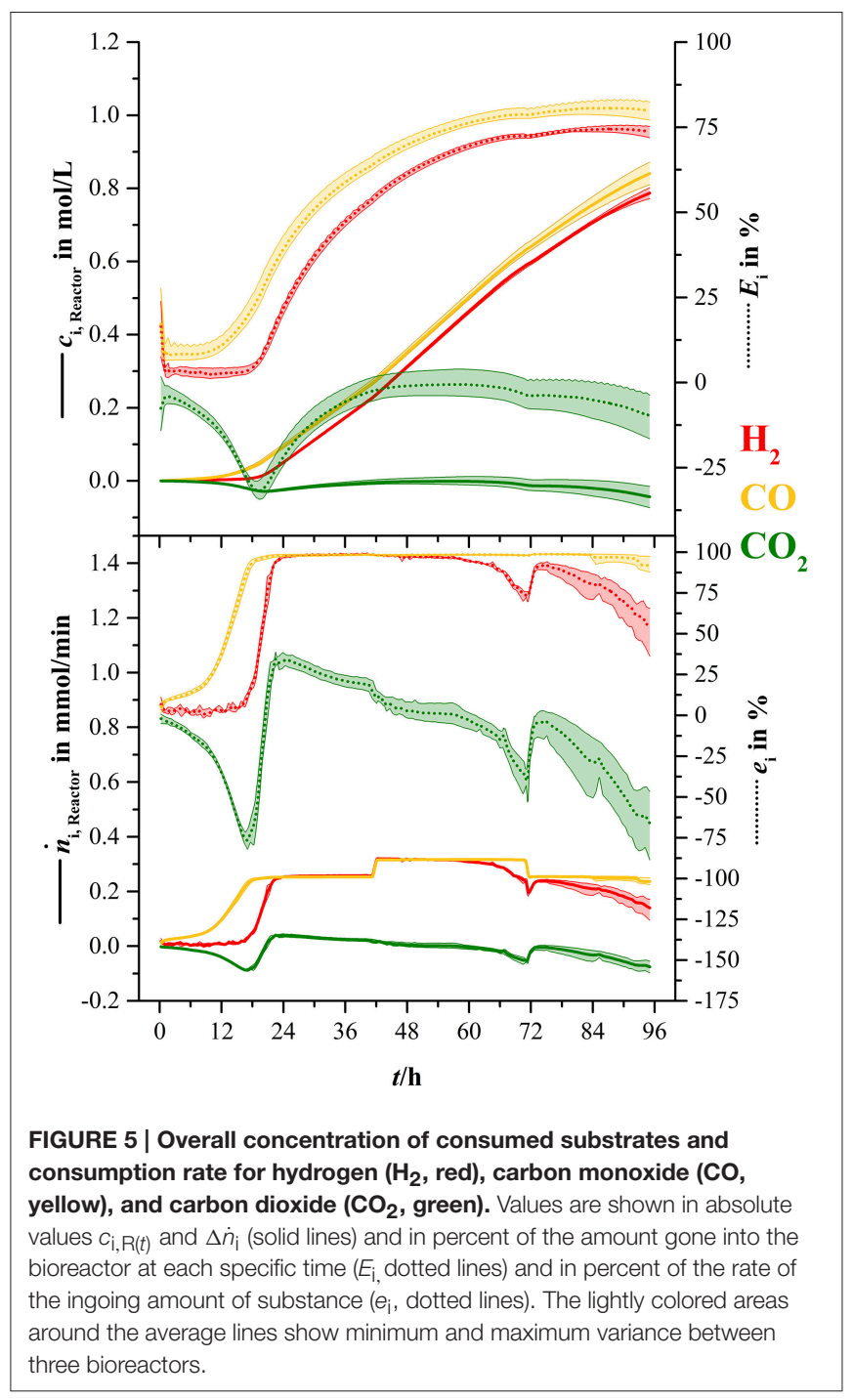

consumed hydrogen started to increase considerably after $18.5 \mathrm{~h}$ and went up to $0.77 \mathrm{~mol}$ or $73.6 \%$ of total hydrogen (dotted red line). Similar to the increase of carbon dioxide in the off-gas in Figure 4, the amount of consumed carbon dioxide decreased down to $-0.03 \mathrm{~mol} / \mathrm{L}$ or $-31.8 \%$ of the amount of carbon dioxide at $19.4 \mathrm{~h}$. From that point, the amount of consumed carbon dioxide increased to $0 \mathrm{~mol} / \mathrm{L}$ and started to decrease down to $-0.05 \mathrm{~mol} / \mathrm{L}(-9.8 \%)$ when hydrogen consumption faded. Uptake rate of carbon monoxide increased continuously during the first $20.2 \mathrm{~h}$, where it reached its maximum average of $0.25 \mathrm{mmol} / \mathrm{min}$ equaling $98 \%$ of the ingoing carbon monoxide stream at that time. Hydrogen uptake rate started to increase at $15.5 \mathrm{~h}$ and reached a maximum average of $0.25 \mathrm{mmol} / \mathrm{min}$ or $98 \%$. At $41.5 \mathrm{~h}$ the uptake rate of carbon monoxide and hydrogen increased to $0.3 \mathrm{mmol} / \mathrm{min}$ due to the elevated gas sparging rate. After $48 \mathrm{~h}$ the hydrogen uptake rate started to decrease and went down to $0.14 \mathrm{mmol} / \mathrm{min}$ at the end of the fermentation.

Directly following the syngas fermentation the reactor was changed to fungal fermentation as stated above. Microbial biomass was not removed. 

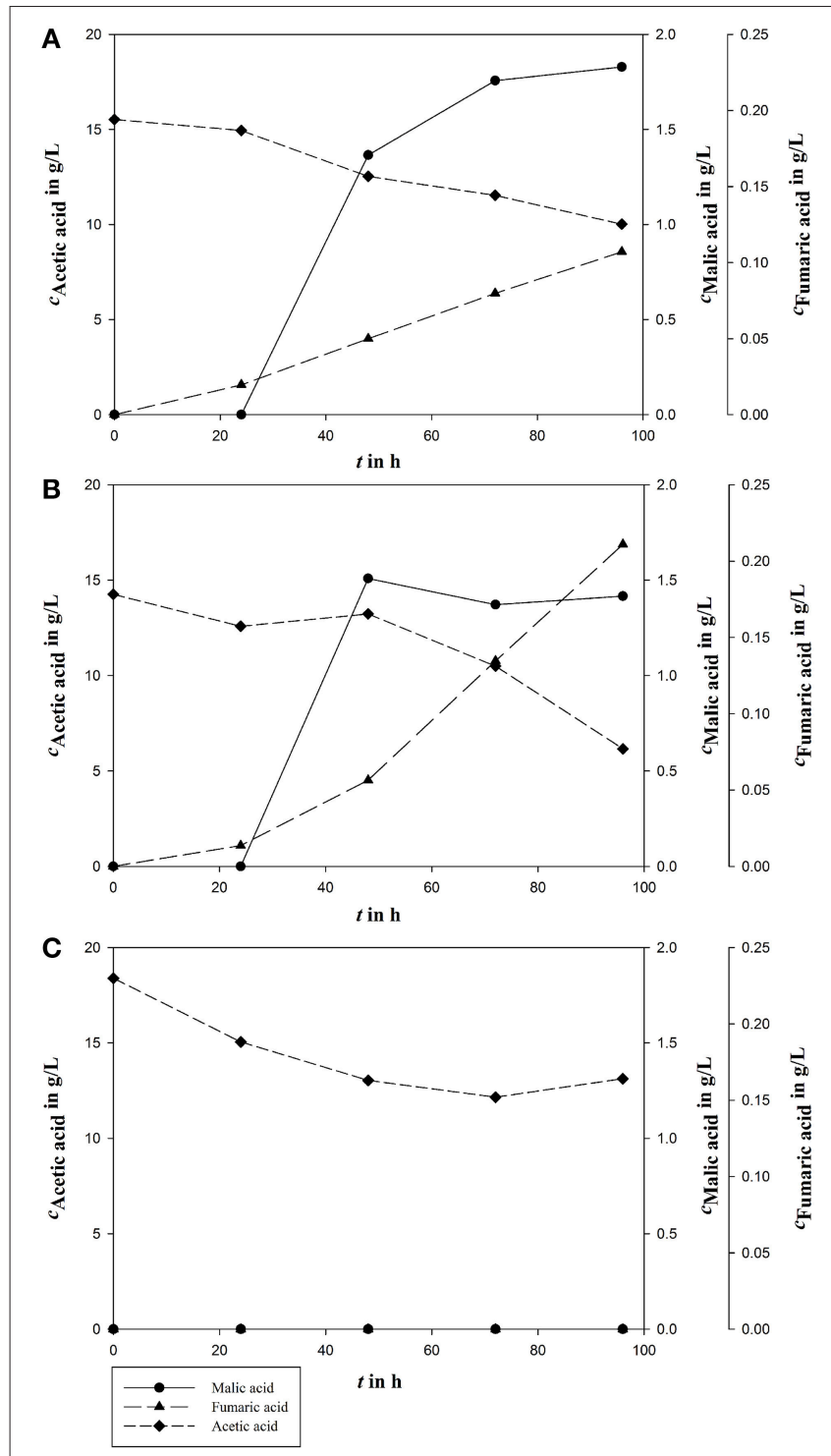

FIGURE 6 | Malic acid production ( $c_{\text {Malic acid }}$ ), and acetic acid ( $\left.c_{\text {Acetic acid }}\right)$ consumption in the three bioreactors A, B, and C from triple approach for syngas fermentation after $96 \mathrm{~h}$ of fermentation. Fumaric acid ( $C_{\text {Fumaric acid }}$ ) is the main side product during $A$. oryzae fermentation.

\section{Sequential Mixed Culture}

The sequential mixed culture was accomplished in three replicates in the described fermentation setup in a bioreactor. Results for malic acid fermentation are shown in Figure 6.

In two of the three bioreactor runs, malic acid production was detected. In one bioreactor, acetic acid was partly metabolized, but no product was formed. In reactor $\mathbf{A}$ acetic acid decreased from $15.53 \mathrm{~g} / \mathrm{L}$ to $10.02 \mathrm{~g} / \mathrm{L}$ during malic acid production of $1.83 \mathrm{~g} / \mathrm{L}$ corresponding to a yield of $0.33 \mathrm{~g} / \mathrm{g}$. In reactor $\mathbf{B}$, the initial acetic acid concentration of $14.26 \mathrm{~g} / \mathrm{L}$ was reduced during fermentation process to $6.15 \mathrm{~g} / \mathrm{L}$ by simultaneous production of $1.42 \mathrm{~g} / \mathrm{L}$ malic acid resulting in a yield of $0.18 \mathrm{~g} / \mathrm{g}$. During cultivation in reactor $\mathrm{C}, 5.39 \mathrm{~g} / \mathrm{L}$ acetic acid was metabolized in total, from initially $18.39 \mathrm{~g} / \mathrm{L}$ to $13.12 \mathrm{~g} / \mathrm{L}$, but without product formation. After $96 \mathrm{~h}$ of fermentation, the three reactors differed greatly. In reactor $\mathbf{A}$ the malic acid concentration decreased to 0 . In reactor $\mathbf{B}$ malic acid concentration increased to $2.02 \mathrm{~g} / \mathrm{L}$ and in reactor $\mathbf{C}$ further no malic acid production could be observed (data not shown).

\section{DISCUSSION}

For the sequential mixed culture fermentation from syngas to malic acid, the main challenges were the requirements of the involved microorganisms in terms of reactor set-up, medium composition and product synthesis. Optimizing product yield and productivity for a certain process usually addresses the needs of the organism involved. Since sequential mixed culture fermentation uses at least two different organisms the key aspect for sequential mixed culture fermentation is either a medium compromise for both organisms or the compatibility of the first (optimized) medium for the second organism in terms of product synthesis. Furthermore, the second organism has to be able to use the product of the first process as a carbon source. The combination of both aspects must be fulfilled to achieve an optimal value added chain from syngas to malic acid.

For the first time, this study shows that A. oryzae is able to use acetic acid, the main product of syngas fermentation, as a proper carbon source for malic acid production. The metabolic pathways and mechanisms are largely understood, when using carbohydrates as carbon source. A partly reductive TCA cycle following on glycolysis and malic acid is synthesized from pyruvic acid and oxaloacetic acid to malic acid (Osmani and Scrutton, 1983; Peleg et al., 1988, 1989; Bercovitz et al., 1990). Fermentative mechanisms for malic acid production from other carbon sources are still not fully known and therefore speculative. For growing on acetic acid, acetyl-CoA synthetase (ACS) was described as a key enzyme for the metabolism of ethanol and acetic acid, which converts acetic acid to acetyl-CoA in C. albicans (Carman et al., 2008). Acetyl-CoA may then enter the glyoxylate cycle which is partly located in the peroxisome and is done for gluconeogenesis. Malic acid occurs in this pathway as an intermediate. This process may be the pathway for malic acid production from acetic acid. This metabolic flux is summarized by Strijbis and Distel (2010).

\section{Preliminary Experiments with C. ljungdahlii}

Cultivation of C. ljungdahlii in medium containing $2.5 \mathrm{~g} / \mathrm{L}$ ammonia chloride for $96 \mathrm{~h}$ resulted in consumption of $0.131 \mathrm{~g} / \mathrm{L}$ ammonia. This equals to a concentration of $0.39 \mathrm{~g} / \mathrm{L}$ ammonia chloride. To ensure that after $96 \mathrm{~h}$ of syngas fermentation no ammonia is left, a total of $0.5 \mathrm{~g}$ ammonia chloride was used for $1.5 \mathrm{~L}$ of medium. The results of preliminary experiments shown in Table 1 indicate that reducing the ammonia concentration in the medium does not negatively affect product formation, substrate consumption and overall product yield, although biomass concentration is slightly lower in $\mathrm{NH}_{4}$-reduced medium. This is consistent with experimental data from Xu et al. (2011) reporting slight differences in biomass concentration in this range of ammonia concentrations. 


\section{Preliminary Experiments with $A$. oryzae}

Comparing the fungal fermentation on acetic acid in the two different media, it could be seen that a reduction of the nitrogen concentration is mandatory. If ammonium is omitted in syngas fermentation medium a similar yield was achieved for malic acid production medium $\left(Y_{\mathrm{P} / \mathrm{S}}\right.$ of $\left.0.28 \mathrm{~g} / \mathrm{g}\right)$ and syngas fermentation medium $\left(Y_{\mathrm{P} / \mathrm{S}}\right.$ of $\left.0.37 \mathrm{~g} / \mathrm{g}\right)$ using acetic acid despite the nitrogen present in malic acid production medium. Although observed yields were similar, malic acid concentration in syngas fermentation medium is approximately half as high as in optimized organic acid production medium $(8.62 \pm 1.15 \mathrm{~g} / \mathrm{L}$ against $4.11 \pm 0.50 \mathrm{~g} / \mathrm{L}$ ) after $168 \mathrm{~h}$. There is also a lack in malic acid production depending on presence of microbial biomass. In medium, containing microbial biomass and with reduced ammonium, malic acid production was firstly detected after $72 \mathrm{~h}$ of cultivation. If microbial biomass was not removed malic acid concentration reached the detection limit already after $48 \mathrm{~h}$. Because biomass itself could be used as source of minerals, nutrients, and vitamins, it might be helpful for the adaption of the fungus to acetic acid as carbon source. Nevertheless, for this sequential mixed culture approach it is a good result that biomass has a positive effect on malic acid production and does not need to be removed. A further challenge was the side product of syngas fermentation, ethanol. As reported in several studies, various concentrations of this alcohol could be produced during cultivation of acetogenic bacteria. With C. ljungdahlii ethanol concentrations of $48 \mathrm{~g} / \mathrm{L}$ could be achieved using syngas from coal as energy and carbon source (Klasson et al., 1993). Our experiments with ethanol as sole carbon source for fungal fermentation showed no malic acid production, so that it can be assumed that ethanol alone in those high concentrations is not a suitable carbon source for A. oryzae. However, the acetic acid/ethanol mixed approach showed the highest yield for malic acid compared to the other acetic acid fermentations $\left(Y_{\mathrm{P} / \mathrm{S}}\right.$ of $0.55 \mathrm{~g} / \mathrm{g}$ ). It was shown that stress conditions for the fungus are beneficial for malic acid production, due to an up-regulation and overexpression of the genes involved in the malic acid production pathway (Knuf et al., 2013). Ethanol as a solvent may lead to stress for $A$. oryzae during cultivation which enhances the product synthesis. It is also possible that ethanol in low concentrations could be metabolized and serves as possible carbon source for malic acid production on the described pathway. In this case the ethanol amounts, produced in this process $(0.75-1.14 \mathrm{~g} / \mathrm{L})$ would not be problematic. All in all the results of preliminary experiment led to the assumption that a sequential mixed culture from syngas to malic acid is a promising approach.

\section{Sequential Mixed Culture from Syngas to Malic Acid}

During the first $18 \mathrm{~h}$ of syngas fermentation C. ljungdahlii was coconsuming fructose and carbon monoxide but did not consume hydrogen. The reason for this could be that $\mathrm{CO}$ is a known inhibitor of hydrogenase activity in Clostridia (Gray and Gest, 1965; Chen and Blanchard, 1978; Kim et al., 1984; Devarapalli et al., 2016). Thus, hydrogen consumption can only start once the carbon monoxide partial pressure in the broth is low enough.
Considerable acetate formation was detectable after consumption of hydrogen started. When the fructose in the medium is depleted and hydrogen consumption starts, the organisms begin to significantly produce acetate. This point was indicated by a temporary increase of the redox potential in the broth.

Up to the time point when hydrogen consumption started to decrease, acetate was continuously produced. This point also marked the beginning of ethanol formation. In case the decrease of hydrogen consumption was due to the increase in the gas sparging rate and therefore the carbon monoxide supply, we reduced the flow rate of syngas to stabilize the uptake rates again. This brought a temporary improvement but hydrogen consumption rate decreased for the rest of the syngas fermentation. The observed occurrence of sudden decrease in hydrogen consumption is a known phenomenon when cultivating $C$. ljungdahlii on syngas as can be seen in Cotter et al. (2009) and Maddipati et al. (2011). However, there is nothing known about why hydrogen consumption decreases.

For the main experiment, average acetate concentration after $96 \mathrm{~h}$ was about $1 \mathrm{~g}$ per liter lower and standard deviation was $0.5 \mathrm{~g}$ per liter higher compared to preliminary bioreactor experiments. The differences in acetate concentration between the three bioreactors might be due to different rates of decreasing hydrogen consumption. In addition, off-gas composition of the bioreactors for $\mathrm{H}_{2}, \mathrm{CO}$, and $\mathrm{CO}_{2}$ showed increasing deviations after the reduction of the ingoing gas stream.

The malic acid production in the three bioreactors with A. oryzae varied widely. Bioreactor $\mathbf{A}$ and $\mathbf{B}$ showed both malic acid production after $48 \mathrm{~h}$ as expected from shake flask experiments. The curve of organic acid production is similar, but reactor $\mathbf{B}$ had already reached a plateau after $48 \mathrm{~h}$, whereas reactor A reached the plateau after $96 \mathrm{~h}$. There is also a spread of $0.15 \mathrm{~g} / \mathrm{L}$ of the yield between bioreactor $\mathbf{A}$ and $\mathbf{B}$. The reason for the lack of malic acid production in reactor $\mathbf{C}$ and the different yields in both other reactors is very difficult to discuss due to the high complexity of the medium composition after syngas fermentation. It seems that small differences in syngas fermentation may have large effects on the following fungal fermentation. Because of that fact, this should not be seen as a triplicate but as three different batches from syngas fermentations. Despite, the fact that interpretation of the results is difficult and the failure in one bioreactor it was clearly shown that malic acid production from syngas by sequential mixed culture fermentation is possible. The overall conversion efficiency of syngas into acetate and ethanol for the syngas fermentation part can be expressed as $Y_{\mathrm{P} / \mathrm{S}}$ of $0.66 \mathrm{~g}$ acetic acid and ethanol per gram of consumed syngas. Combined with the $Y_{\mathrm{P} / \mathrm{S}}$ for the conversion of acetic acid into malic acid we achieved an overall $Y_{\mathrm{P} / \mathrm{S}}$ for the conversion of $\mathrm{CO}$ and $\mathrm{H}_{2}$ into malic acid of 0.22 $\mathrm{g} / \mathrm{g}$ (3.5 g malic acid per mol syngas consumed) for reactor $\mathbf{A}$ and $0.12 \mathrm{~g} / \mathrm{g}$ ( $1.9 \mathrm{~g}$ malic acid per mol syngas consumed) for reactor $\mathbf{B}$. This was achieved with complete conversion of $\mathrm{CO}$ and $\mathrm{H}_{2}$ into products. Since there are no reported processes for production of malic acid from syngas we compare our yields with anaerobic production of other $\mathrm{C}_{4}$ molecules. Anaerobic processes for production of butanol from sugars described in literature 
gave $Y_{\mathrm{P} / \mathrm{S}}$ values between $0.1 \mathrm{~g} / \mathrm{g}$ and $0.3 \mathrm{~g} / \mathrm{g}$ when using $C$. beijerinckii or $C$. acetobutylicum and sugar from lignocellulosic substrates as a carbon source (Schiel-Bengelsdorf et al., 2013). Using syngas for production of butanol as did Lewis et al. (2007) yielded $0.08 \mathrm{~g}$ butanol per gram of consumed carbon monoxide. Other processes for production of $\mathrm{C}_{4}$-molecules using anaerobic organisms and syngas as a substrate described in literature do not state $Y_{\mathrm{P} / \mathrm{S}}$ values which prevents proper comparison.

Although sequential mixed cultures have been used for centuries in food industry, e.g., sake production, applications for production of value added chemicals is rare. It could be shown, that this kind of biotechnological process is suitable for the production of low price chemicals like single cell oils for biofuel production ( $\mathrm{Hu}$ et al., 2016). There are also some approaches for interlinking cultivations, like cocultivating a homoacetogen (e.g., C. ljungdahlii) and an anaerobic organism that is able to grow on syngas, ethanol or acetate and produces butyrate or butanol as described by Datta and Reeves (2014), a combination of algae and yeast fermentation (Dillschneider et al., 2014), dextran fermentation (Kim and Day, 1994) and biogas production, but sequential fermentations are rare.

\section{CONCLUSION}

We could successfully show that production of high-value L-malate from syngas is possible. Further increase of yield is feasible as the process medium was neither optimized for acetic acid production nor for malic acid production and only wild type strains of $C$. ljungdahlii and A. oryzae were used. Both strains are available at the DSMZ. The advantage of this kind of biotechnological process is the extension of the product portfolio of anaerobic syngas fermentation. Because of the toxicity of oxygen to Clostridia, there is no further step necessary than changing the sparging from syngas to air, to prepare the medium for fungal fermentation. The work at hand demonstrates that $A$. oryzae is able to use acetic acid as a substrate for malic acid formation. Moreover it shows that it is possible to link anaerobic syngas fermentation and aerobic malic acid production using sequential mixed cultures of $C$. ljungdahlii and $A$. oryzae. In doing so we not only broadened the feedstock for malic acid production from glycerol and sugars to the whole feedstock of gasification processes but also reported the

\section{REFERENCES}

Barratt, R. W., Johnson, G. B., and Ogata, W. N. (1965). Wild-Type and mutant stocks of aspergillus nidulans. Genetics 52, 233-246.

Battat, E., Peleg, Y., Bercovitz, A., Rokem, J. S., and Goldberg, I. (1991). Optimization of L-Malic acid production by Aspergillus flavus in a stirred fermentor. Biotechnol. Bioeng. 37, 1108-1116. doi: 10.1002/bit.260371117

Bengelsdorf F., Straub, M., and Dürre, P. (2013). Bacterial synthesis gas (syngas) fermentation. Environ. Technol. 34, 1639-1651. doi: 10.1080/09593330.2013.827747

Bercovitz, A., Peleg, Y., Battat, E., Rokem, J., S., and Goldberg, I. (1990). Localization of pyruvate carboxylase in organic acid-producing aspergillus strains. Appl. Environ. Microbiol. 56, 1594-1597. highest yields to date for the production of $\mathrm{C}_{4}$ components from syngas.

\section{AUTHOR CONTRIBUTIONS}

FO: Substantial performance of the experiments with C. liundahlii and the anaerobic part. Writing, as co-first author, the syngas part of the manuscript and parts of introduction and Discussion. SD: Substantial performance of the experiments with $A$. oryzae and the aerobic part. Writing, as co-first author, the fungal part of the manuscript and parts of introduction and Discussion. SD and FO are co-first authors and contributed equally to the paper. NV: Substantial performance of the experiments with $A$. oryzae and the aerobic part. MZ: Substantial performance of the experiments with C. ljundahlii and the anaerobic part. AN: Substantial contribution to the conception of the syngas fermentation and critically revising of the final version to be published. KO: Substantial contribution to the conception of the fungal fermentation and critically revising of the final version to be published. CS: Substantial contribution to the idea of the coupling fermentation and critical revision of the work for important intellectual content.

\section{ACKNOWLEDGMENTS}

This work by SD was supported by a grant from the Ministry of Science, Research, and the Arts of Baden-Württemberg Az.: 337533-10-5/75B as part of the BBW ForWerts Graduate Program. Work of FO was supported by a grand from the Ministry of Science, Research, and the Arts of Baden-Württemberg Az.: 337533-6-195/7/1 and Az.: 33-7533-6-195/7/9 as part of the BW ${ }^{2}$ Graduate Program. We want to thank the group of Prof. Clemens Posten, Section for Bioprocess Engineering of the Institute of Process Engineering in Life Sciences for conducting the ion chromatography measurements for determination of $\mathrm{NH}_{4}^{+}$. We acknowledge support by Deutsche Forschungsgemeinschaft and Open Access Publishing Fund of Karlsruhe Institute of Technology.

\section{SUPPLEMENTARY MATERIAL}

The Supplementary Material for this article can be found online at: http://journal.frontiersin.org/article/10.3389/fmicb. 2016.00891

Bredwell, M., and Worden, R. (1998). Mass-transfer properties of microbubbles. 1. experimental studies. Biotechnol. Prog. 14, 31-38.

Brown, S. H., Bashkirova, L., Berka, R., Chandler, T., Doty, T., McCall, K., McCulloch, M., et al. (2013). Metabolic engineering of Aspergillus oryzae NRRL 3488 for increased production of L-Malic acid. Appl. Microbiol. Biotechnol. 97, 8903-8912. doi: 10.1007/s00253-013-5132-2

Carman, A. J., Vylkova, S., and Lorenz, M. C. (2008). Role of acetyl coenzyme a synthesis and breakdown in alternative carbon source utilization in candida albicans. Eukaryotic Cell 7, 1733-1741. doi: 10.1128/EC.00253-08

Chen, J.-S., and Blanchard, D. K. (1978). Isolation and Properties of a unidirectional $\mathrm{H}_{2}$-oxidizing hydrogenase from strictly anaerobic $\mathrm{N}_{2}$-fixing bacterium Clostridium pasteurianum W5. Biochem. Biophys. Res. Commun. 84, 1144-1150. doi: 10.1016/0006-291X(78)91703-5 
Cotter, J. L., Chinn, M. S., and Grunden, A. M. (2009). Influence of process parameters on growth of Clostridium ljungdahlii and Clostridium autoethanogenum on synthesis gas. Enzyme Microb. Technol. 44, 281-288. doi: 10.1016/j.enzmictec.2008.11.002

Daniell, J., Köpke, M., and Simpson, S. D. (2012). Commercial biomass syngas fermentation. Energies 5, 5372-5417. doi: 10.3390/en5125372

Datta, R., and Reeves, A., (2014). Syntropic Co-Culture of Anaerobic Microorganism for Production of n-Butanol from Syngas. US patent no. US 2014/0206066 A1.

Demler, M., and Weuster-Botz, D. (2011). Reaction engineering analysis of hydrogenotrophic production of acetic acid by Acetobacterium woodii. Biotechnol. Bioeng. 108, 470-474. doi: 10.1002/bit.22935

Devarapalli, M., Atiyeh, H. K., Phillips, J. R., Lewis, R. S., and Huhnke, R., L. (2016). Ethanol production during semi-continuous syngas fermentation in a trickle bed reactor using Clostridium ragsdalei. Bioresour. Technol. 209, 56-65 doi: 10.1016/j.biortech.2016.02.086

Diekert, G., and Wohlfarth, G. (1994). Matabolism of homoacetogens. Antonie van Leeuwenhoek 66, 209-221.

Dillschneider, R., Schulze, I., Neumann, A., Posten, C., and Syldatk, C. (2014). Combination of algae and yeast fermentation for an integrated process to produce single cell oils. Appl. Microbiol. Biotechnol. 98, 7793-7802. doi: 10.1007/s00253-014-5867-4

Gray, C. T., and Gest, H. (1965). Biological formation of molecular hydrogen. Science 148, 186-192.

Hammerschmidt, A., Boukis, N., Hauer, E., Galla, U., Dinjus, E., Hitzmann, B., Larsen, T., and Nygaard, S. D. (2011). Catalytic conversion of waste biomass by hydrothermal treatment. Fuel 90, 555-562. doi: 10.1016/j.fuel.2010.10.007

Hu, P., Chakraborty, S., Kumar, A., Woolston, B. M., Liu, H., Emerson, D., et al. (2016). Integrated bioprocess for conversion of gaseous substrates to liquids. Proc. Natl. Acad. Sci. U.S.A. 113, 3773-3778. doi: 10.1073/pnas.1516867113

Kim, B. H., Bellows, P., Datta, R., and Zeikus, J. G. (1984). Control of carbon and electron flow in Clostridium acetobutylicum fermentations: utilization of carbon monoxide to inhibit hydrogen production and enhance butanol yields. Appl. Environ. Microbiol. 48, 764-770.

Kim, D., and Day, D. F. (1994). A new process for the production of clinical dextran by mixed-culture fermentation of lipomyces starkeyi and Leuconostoc mesenteroides. Enzyme Microb. Technol. 16, 844-848. doi: 10.1016/01410229(94)90058-2

Klasson, K. T., Ackerson, M. D., Clausen, E. C., and Gaddy, J. L. (1993). Biological conversion of coal and coal-derived synthesis gas. Fuel 72, 1673-1678. doi: 10.1016/0016-2361(93)90354-5

Knuf, C., Nookaew, I., Brown, S. H., McCulloch, M., Berry, A., and Nielsen, J. (2013). Investigation of malic acid production in Aspergillus oryzae under nitrogen starvation conditions. Appl. Environ. Microbiol. 79, 6050-6058. doi: 10.1128/AEM.01445-13

Köpke, M., Mihalcea, C., Liew, F. M., Tizard, J. H., Ali, M. S., Conolly, J. J., AlSinawi, B., and Simpson, S. D. (2011). 2,3-butanediol production by acetogenic bacteria, an alternative route to chemical synthesis, using industrial waste gas. Appl. Environ. Microbiol. 77, 5467-5475. doi: 10.1128/AEM.00355-11

Lee, J. W., Kim, H. U., Choi, S., Yi, J., and Lee, S. Y., (2011). Microbial production of building block chemicals and polymers. Curr. Opin. Biotechnol. 22, 758-767. doi: 10.1016/j.copbio.2011.02.011

Lewis, R. S., Tanner, R. S., and Huhnke, R. L. (2007). Indirect or Direct Fermentation of Biomass to Fuel Alcohol. US patent no. US 2007/0275447 A1.

Lohbeck, K., Haferkorn, H., Fuhrmann, W., and Fedtke, N. (2000). "Maleic and fumaric acids," in Ullmann's Encyclopedia of Industrial Chemistry, ed B. Elvers (Weinheim: Wiley-VCH Verlag GmbH \& Co. KGaA), 145-155.

Maddipati, P., Atiyeh, H. K., Bellmer, D. D., and Huhnke, R. L. (2011). Ethanol production from syngas by Clostridium strain P11 using corn steep liquor as a nutrient replacement to yeas extract. Bioresour. Technol. 102, 6494-6501.

Miltenberger, K. (2000). "Hydroxycarboxylic acids, aliphatic," in Ullmann's Encyclopedia of Industrial Chemistry, ed B. Elvers (Weinheim: Wiley-VCH Verlag GmbH \& Co. KGaA), 481-492.

Moon, S. Y., Hong, S. H., Kim, T. Y., and Lee, S. Y. (2008). Metabolic engineering of escherichia coli for the production of malic acid. Biochem. Eng. J. 40, 312-320. doi: 10.1016/j.bej.2008.01.001
Schuchmann, K., and Müller, V. (2014). Autotrophy at the thermodynamic limit of life: a model for energy conservation in acetogenic bacteria. Nat. Rev. Microbiol. 12, 809-821. doi: 10.1038/nrmicro3365

Neumann, A., Dörsam, S., Oswald, F., and Ochsenreither, K. (2015). "Microbial production of value added chemicals from pyrolysis oil and syngas," in Sustainable Production of Bulk Chemicals, ed M. Xian (Dordrecht: Springer Science+Buisness), 69-105.

Ochsenreither, K., Fischer, C., Neumann, A., and Syldatk, C. (2014). Process characterization and influence of alternative carbon sources and carbon-tonitrogen ratio on organic acid production by Aspergillus oryzae DSM1863. Appl. Microbiol. Biotechnol. 98, 5449-5460. doi: 10.1007/s00253-014-5614-x

Osmani, S. A., and Scrutton, M. C. (1983). The sub-cellular localisation of pyruvate carboxylase and of some other enzymes in Aspergillus nidulans. Eur. J. Biochem. 133, 551-560. doi: 10.1111/j.1432-1033.1983.tb07499.x

Peleg, Y., Barak, A., Scrutton, M. C., and Goldberg, I. (1989). Malic acid accumulation by Aspergillus flavus.III. 13C NMR and isoenzyme analysis. Appl. Microbiol. Biotechnol. 30, 176-83. doi: 10.1007/BF00264008

Peleg, Y., Stieglitz, B., and Goldberg, I. (1988). Malic acid accumulation by Aspergillus flavus - I. biochemical aspects of acid biosynthesis. Appl. Microbiol. Biotechnol. 28, 69-75. doi: 10.1007/BF00250501

Rokni, M. (2015). Thermodynamic analyses of municipal solid waste gasification plant integrated with solid oxide fuel cell and stirling hybrid system. Int. J. Hydrogen Energy. 40, 7855-7869. doi: 10.1016/j.ijhydene.2014.11.046

Schiel-Bengelsdorf, B., Montoya, J., Linder, S., and Dürre, P. (2013). Butanol fermentation. Environ. Technol. 34, 1691-1710. doi: 10.1080/09593330.2013.827746

Song, M. H., Nah, J.-Y., Han, Y. S., Han, D. M., and Chae, K.-S. (2001). Promotion of conidial head formation in Aspergillus oryzae by a salt. Biotechnol. Lett. 23, 689-691. doi: 10.1023/A:1010308601469

Strijbis, K., and Distel, B. (2010). Intracellular Acetyl Unit Transport in Fungal Carbon Metabolism. Eukaryotic Cell 9, 1809-1815. doi: 10.1128/EC.00172-10

Tanner, R. (2007). "Cultivation of bacteria and fungi," in Manual of Enviromental Microbiology, 3rd Edn, eds C. J. Hurst, R. L. Crawford, J. L. Garland, D. A. Lipson, A. L. Mills, and L. D. Stetzenbach (Washington, DC: ASM Press), 69-78.

Werpy, T., and Petersen, G. (2004). Top Value Added Chemicals from Biomass Volume I-Results of Screening for Potential Candidates from Sugars and Synthesis Gas Top Value Added Chemicals from Biomass Volume I?: Results of Screening for Potential Candidates. Washington: U.S. Department of Energy.

Xu, D., Tree, D. R., and Lewis, R. S. (2011). The effects of syngas impurities on syngas fermentation to liquid fuels. Biomass Bioener. 35, 2690-2696. doi: 10.1016/j.biombioe.2011.03.005

Zelle, R. M., de Hulster, E., van Winden, W. A., de Waard, P., Dijkema, C., Winkler, A. A., et al. (2008). Malic acid production by saccharomyces cerevisiae: engineering of pyruvate carboxylation, oxaloacetate reduction, and malate export. Appl. Environ. Microbiol. 74, 2766-2777. doi: 10.1128/AEM.02591-07

Zhang, C., Yang, H., Yang, F., and Ma, Y., (2009). Current progress on butyric acid production by fermentation. Curr. Microbiol. 59, 656-663 doi: 10.1007/s00284009-9491-y

Zhang, X., Wang, X., Shanmugam, K. T., and Ingram, L. O., (2011). LMalate production by metabolically engineered escherichia coli. Appl. Environ. Microbiol. 77, 427-434. doi: 10.1128/AEM.01971-10

Conflict of Interest Statement: The authors declare that the research was conducted in the absence of any commercial or financial relationships that could be construed as a potential conflict of interest.

Copyright (C) 2016 Oswald, Dörsam, Veith, Zwick, Neumann, Ochsenreither and Syldatk. This is an open-access article distributed under the terms of the Creative Commons Attribution License (CC BY). The use, distribution or reproduction in other forums is permitted, provided the original author(s) or licensor are credited and that the original publication in this journal is cited, in accordance with accepted academic practice. No use, distribution or reproduction is permitted which does not comply with these terms. 